\title{
Relation between creatinine and uric acid excretion
}

\author{
Y Nishida
}

\begin{abstract}
The relation between creatinine and uric acid metabolism was analysed in 77 male patients with primary gout and 62 healthy male subjects. Significant positive correlations between 24 hour urinary creatinine and uric acid excretion were shown in both groups. The mean urinary creatinine and uric acid excretions in the patients with gout were significantly increased as compared with those of normal male controls. These results suggest that there is a close correlation between creatinine and uric acid synthesis. In addition, it seems that accelerated uric acid synthesis seen in some patients with gout is due to increased creatinine synthesis.
\end{abstract}

Hyperuricaemia is caused by accelerated uric acid synthesis or impaired renal excretion of uric acid, or a combination of both events. Superactivity of phosphoribosyl pyrophosphate synthetase $^{12}$ and decreased activity of hypoxanthine-guanine phosphoribosyltransferase ${ }^{3-5}$ are known to be mechanisms of uric acid overproduction. However, the prevalence of these enzyme abnormalities in patients with gout is rare. ${ }^{6}$

Recently, accelerated degradation of ATP, which occurs during the metabolism of fructose $^{7-9}$ and ethanol, ${ }^{10}$ was confirmed as the mechanism of uric acid overproduction. Tissue hypoxia $^{11} 12$ and strenuous muscle exercise ${ }^{13} 14$ were also shown to cause accelerated ATP degradation. The increased urate synthesis seen in patients with primary gout may not be caused by these mechanisms, however.

The relation between creatinine and uric acid metabolism has not been studied previously. Figure 1 shows that excessive production of creatinine may result in increased degradation of $S$-adenosylmethionine and ATP, which would increase the synthesis of uric acid. In this report we measured the urinary creatinine and uric acid excretion in patients with primary gout.

\section{Materials and methods}

Blood and 24 hour urine samples were collected from 77 male patients with primary gout diagnosed by the New York diagnostic criteria and from 62 healthy male subjects receiving a purine restricted diet and no drugs. Patients with abnormal phosphoribosyl pyrophosphate synthetase and hypoxanthine-guanine phosphoribosyltransferase activities were excluded.

Uric acid and creatinine concentrations were determined in plasma and urine samples. Uric acid concentration was measured by the enzymic methods of Liddle $e t a l,{ }^{15}$ and creatinine concentration by the method of Folin and $\mathrm{Wu}^{16}$ using a commercially supplied Wako kit. Clearance rates for creatinine and uric acid were calculated. Statistical analysis was performed with an $F$ test.

\section{Results}

The table summarises the results. Mean levels of body weight, plasma uric acid, and plasma creatinine in patients with gout were significantly higher than those of normal controls. The mean 24 hour urinary creatinine and urate excretions of patients with gout were also significantly higher than those of control subjects. There was no significant difference in the mean values of creatinine clearance between patients with gout and controls. The mean urate clearance in patients with gout was significantly lower than that of normal male controls. Figure 2 shows significantly positive correlations between 24 hour urinary excretion of creatinine and uric acid in patients with gout and controls.

Summary of data from patients with gout and control subjects. Results are given as mean (SD)

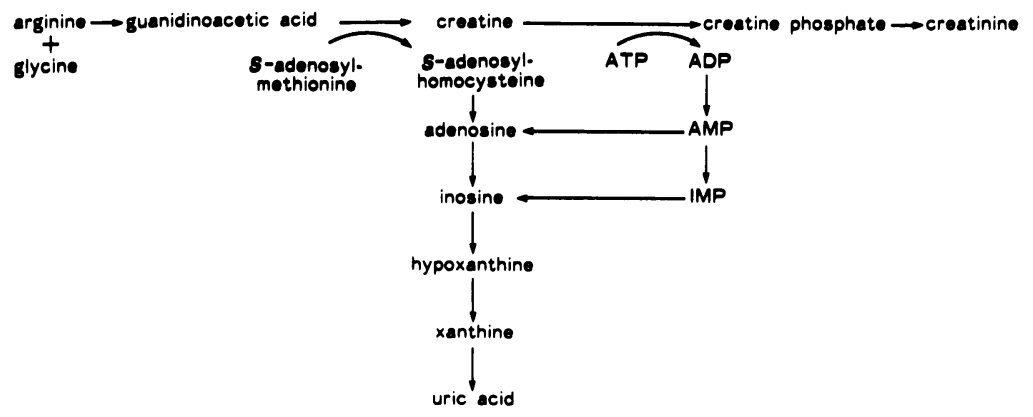

Figure 1 Relation between creatinine and purine metabolism.

\begin{tabular}{|c|c|c|}
\hline & $\begin{array}{l}\text { Patients with } \\
\text { gout } \\
(n=77)\end{array}$ & $\begin{array}{l}\text { Controls } \\
(n=62)\end{array}$ \\
\hline $\begin{array}{l}\text { Age (years) } \\
\text { Body weight (kg) } \\
\text { Plasma }\end{array}$ & $\begin{array}{l}46.3(12.4) \\
67.8(10.9)^{*}\end{array}$ & $\begin{array}{l}42 \cdot 2(15 \cdot 6) \\
63 \cdot 2(8 \cdot 8)\end{array}$ \\
\hline $\begin{array}{l}\text { Uric acid (mmol/l) } \\
\text { Creatinine ( }(\mu \mathrm{mol} / 1 \\
\text { Urinary excretion }\end{array}$ & $\begin{array}{l}0.54(0.09)^{* *} \\
106(27)^{* *}\end{array}$ & $\begin{array}{l}0.35(0.09) \\
80(18)\end{array}$ \\
\hline $\begin{array}{l}\text { Urinary excretion } \\
\text { Uric acid }(\mathrm{mmol} / 24 \mathrm{~h}) \\
\text { Creatinine }(\mathrm{mmol} / 24 \mathrm{~h}) \\
\text { Clearance }\end{array}$ & $\begin{array}{l}4 \cdot 7(1 \cdot 5)^{* *} \\
13 \cdot 3(4 \cdot 0)^{* *}\end{array}$ & $\begin{array}{l}3 \cdot 6(1 \cdot 3) \\
11 \cdot 4(3 \cdot 2)\end{array}$ \\
\hline $\begin{array}{l}\text { Uric acid }(\mathrm{ml} / \mathrm{min}) \\
\text { Creatinine }(\mathrm{ml} / \mathrm{min})\end{array}$ & $\begin{array}{l}6 \cdot 6(2 \cdot 9)^{* * *} \\
97 \cdot 9(51 \cdot 1)\end{array}$ & $\begin{array}{l}7.8(3.6) \\
99 \cdot 3(21 \cdot 5)\end{array}$ \\
\hline
\end{tabular}

*p<0.05; "*p<0.01. 

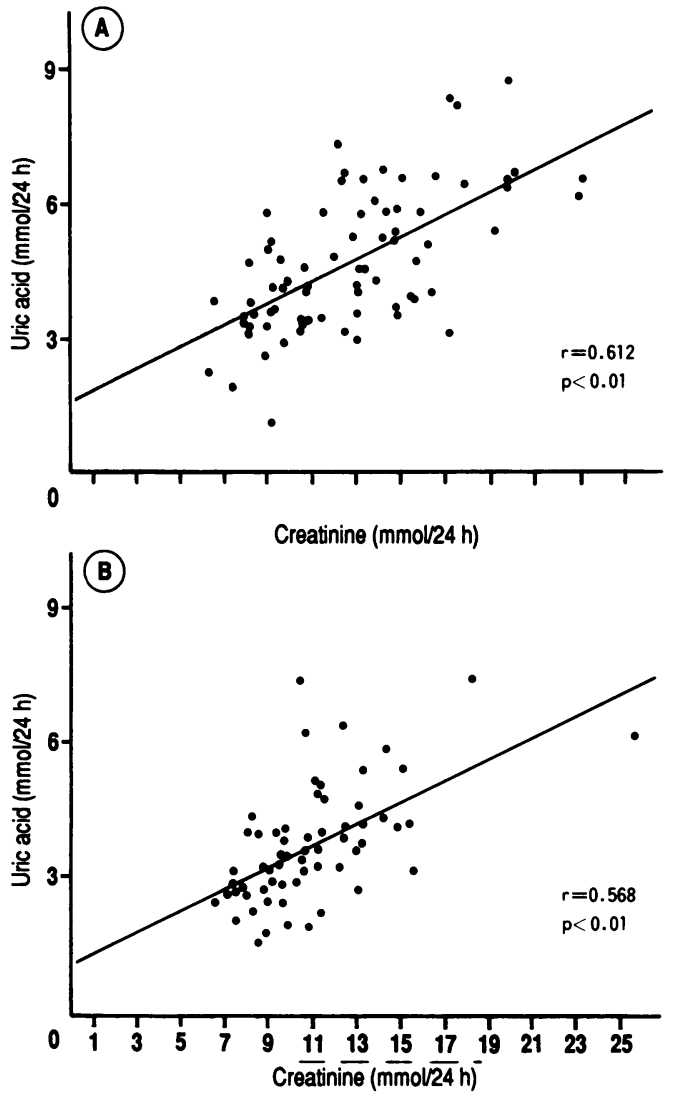

Figure 2 Correlation between 24 hour urinary excretion of creatinine and uric acid in $(A)$ patients with primary gout; (B) normal male subjects.

\section{Discussion}

In this study significant positive correlation between 24 hour urinary creatinine and uric acid excretion was shown. In the steady state urinary excretion of uric acid over 24 hours is thought to represent the urate production over the same period. ${ }^{17}$ Although 24 hour urinary excretion of creatinine may be affected by the dietary creatine content, it seems that there is a close association between creatinine and uric acid synthesis.

One possible mechanism for this association is the increased supply of creatine from the diet. This exogenous creatine is subsequently metabolised to creatine phosphate, then creatinine. The phosphate donor is ATP. Increased degradation of ATP has been shown to cause accelerated urate synthesis. ${ }^{7-14}$

Another possible mechanism for the association between creatinine and uric acid synthesis is endogenous creatine synthesis, by methylation of guanidinoacetic acid. In this reaction $S$ - adenosylmethionine is converted to $S$-adenosylhomocysteine, which is then catalysed to adenosine. Accelerated creatine synthesis may cause increased synthesis of adenosine, which is degraded subsequently to inosine, hypoxanthine, xanthine, and uric acid. Fasting subjects excreted 400 to $900 \mathrm{mg}$ of creatinine in 24 hours, indicating endogenous creatine synthesis (data not shown). It seems, therefore, that large amounts of adenosine are produced by methylation.

In addition, patients with gout had increased 24 hour urinary creatinine and uric acid excretion. Although this study did not measure either endogenous creatinine or uric acid synthesis directly, it is possible that the hyperuricaemia seen in some patients with primary gout is due to accelerated endogenous creatinine synthesis.

We are carrying out further studies of the relation between creatinine and uric acid metabolism in animals.

1 Sperling O, Eilam G, Persky-Brosh S, de Vries A. Accelerated erythrocyte 5-phosphoribosyl-1-pyrophosphate synthesis. A familial abnormality associated with excessive uric acid production and gout. Biochem Med 1972; 6: 310-6.

2 Becker M A, Meyer L J, Seegmiller J E. Gout with purine overproduction due to increased phosphoribosylpyrophosphate synthetase activity. Am $\mathcal{F}$ Med 1973; 55: 232-42.

3 Lesch M, Nyhan W L. A familial disorder of uric acid metabolism and central nervous system function. Am $\mathcal{f}$ Med 1964; 36: 561-70.

4 Seegmiller J E, Rosenbloom F M, Kelley W N. Enzyme defect associated with a sex-linked human neurological disorder and excessive purine synthesis. Science 1967; 155: 1682-4.

5 Kelley W N, Rosenbloom F M, Henderson J F, Seegmiller $J$ E. A specific enzyme defect in gout associated with overproduction of uric acid. Proc Natl Acad Sci USA 1967; 57: 1735-9.

6 Morton N E, Lalouel J M. Genetic epidemiology of LeschNyhan disease. Am ₹ Hum Genet 1977; 29: 304-7.

7 Fox I H. Adenosine triphosphate degradation in specific disease. F Lab Clin Med 1985; 106: 101-10.

8 Fox I H. Metabolic basis for disorders of purine nucleotide degradation. Metabolism 1981; 30: 616-34.

9 Fox I H, Kelly W N. Studies on the mechanism of fructose induced hyperuricemia in man. Metabolism 1972; 21 : 713-21.

10 Faller J, Fox I H. Ethanol-induced hyperuricemia. Evidence for increased urate production by activation of adenine

11 Woolliscroft J O, Colfer $\mathrm{H}$, Fox I $\mathrm{H}$. Hyperuricemia in acute illness: a poor prognostic sign. Am $\mathcal{F}$ Med 1982; 72: 58-62.

12 Fox I H, Palella T D, Kelley W N. Hyperuricemia: a marker for cell energy crisis. $N$ Engl $\mathcal{Y}$ Med 1987; 317: 111-2.

13 Sutton J R, Toews C J, Ward G R, Fox I H. Purine metabolism during strenuous muscular exercise in man. metabolism during strenuous

14 Green H J, Fraser I G. Differential effects of exercise intensity on serum uric acid concentration. Med Sci Sports Exerc 1988; 20: 55-9.

15 Liddle L, Seegmiller J E, Laster L. The enzymatic spectrophotometric method for determination of uric acid. $\mathbf{f}$ Lab Clin Med 1959; 54: 903-13.

16 Bonsnes $R \mathbb{W}$, Taussky $\mathrm{H} \mathrm{H}$. On the colorimetric determination of creatinine by the Jaffe reaction. $\mathcal{F}$ Biol Chem 1945; 158: 581-91.

17 Seegmiller J E, Grayzel A I, Laster L, et al. Studies of uric acid pool size and turnover rate. Ann Rheum Dis 1969; 28: 366-73. 